\title{
Die relasie tussen grondbesit en die sosiale struktuur van Palestina in die Herodiaanse tyd ${ }^{1}$
}

\author{
G J Volschenk \\ Departement Nuwe-Testamentiese Wetenskap \\ Universiteit van Pretoria
}

\begin{abstract}
The relationship between land tenancy and social structure of Palestine in the Herodian era

The article describes the relationship between land tenancy and social structure of Palestine. Secondly it describes the conflicting perceptions of land tenancy within the social structure of Palestine. The conflicting perceptions of land tenancy led to conflict between the elite and the peasants. This conflict was intensified by the hierarchical social structure of Palestine. The article concludes that the use of the social scientific model of the social structure of Palestine prevents anachronism and reductionism in the interpretation of biblical evidence regarding land tenancy.
\end{abstract}

\section{INLEIDING}

Die onderhawige artikel bespreek die relasie tussen grondbesit en die sosiale struktuur in Palestina. In afdeling 2.1 word die twee botsende persepsies oor grondbesit beskryf. Die Israelitiese persepsie is dat die land aan God behoort en dat dit aan die volk geleen word. Dit is die relasionele of familiale persepsie oor grond. Die Romeine of elite se persepsie is dat grond 'n verhandelbare kommoditeit is. In afdeling 2.2 word die relasie tussen grondbesit en verskillende groepe mense beskryf. Die botsende persepsies oor grondbesit het aanleiding

\footnotetext{
${ }^{1}$ Dr Gert $\mathrm{J}$ Volschenk (MDiv, DD) is as navorsingsassosiaat betrokke by prof dr Andries G van Aarde se navorsingsprojek "Bybelse Teologie en Hermeneutiek", Departement Nuwe Testamentiese Wetenskap, Fakulteit Teologie, Universiteit van Pretoria.
} 
gegee tot konflik tussen die elite en die kleinboere wat later uitgeloop het op die kleinboeropstande. Die kleinboere is sistematies verarm en verkneg deur skuld sodat die uiteinde van die proses grondloosheid en slawerny is (kyk afdeling 2.4). afdeling 2.5 word tot die gevolgtrekking gekom dat "armes" in die eerste-eeuse Mediterreense wêreld nie slegs 'n ekonomiese klas was nie, maar die sosiaal veragtes. In afdeling 3 word die sosiale struktuur van Palestina beskryf waaruit die relasie met grondbesit na vore kom. Die gevolgtrekking is dat die gebruik van die sosiaal-wetenskaplike model van die sosiale struktuur van Palestina die gevare van anakronisme en reduksionisme voorkom wat kenmerkend is van Marxisme. Die botsende persepsies oor grondbesit is deur die hiërargiese sosiale struktuur van Palestina geïntensifiseer wat weer die eksploiterende relasie tussen die elite en kleinboere beklemtoon.

\section{GRONDBESIT OF GRONDONTEIENING}

\subsection{Grondbesit}

Daar is konsensus onder geleerdes dat daar in die eerste eeu twee botsende persepsies oor grond was (vgl Davies 1974:15-53; Brueggemann 1977:3; Fiensy 1991:3): Eerstens, die Ou-Testamentiese beginsel en ideaal van individuele onafhanklikheid. Tweedens, die nuwe Romeinse idee dat grond die bron van profyt was, dit wil sê 'n verhandelbare kommoditeit. Laasgenoemde persepsie het sosiale klasvorming aangewakker. Die twee beskouings het parallel teenoor mekaar bestaan: Die elite groep wat die profyt uit die grond gemaak het en die kleinboere wat altyd op een of ander manier die elite gedien het (Oakman 1986:38; 1991:157; Fiensy 1991:4).

Grondbesit vanuit die perspektief van die rykes, dit wil sê van bo, word uitgedruk in territoriale en wettiese terme. Grondbesit vanuit die perspektief van die kleinboer, dit wil sê van onder, word uitgedruk in gewoontereg of binne familiale verband. Die model vir grondbesit in die eerste-eeuse Palestina word grotendeels bepaal deur die groep wie se belange gedien word. Die rykes het territoriaal gedink en die kleinboerbesitters het relasioneel gedink. Die rykes het besef dat grondgebied wat hulle bykry, groter inkomste beteken het. Inkomste 
het dus vir die elite in direkte verhouding gestaan met die gebied wat hulle beheer het. Daar was ook verskillende kategorieë van grondbesit: koninklike gebied, vestigingsgebied en dorpsgebied (Oakman 1986:38; Fiensy 1991:2, 3).

Die teologiese betekenis van die land beteken vir die Israeliete eerstens dat die land die beloofde land is (Gen 12:1-3). God het dit aan hulle voorvaders belowe. Die persepsies kom ook by die Judaïsme en in die Hellenistiese periode voor (vgl Jub 13:3; Test van Moses 2:1; Sirag 46:8). Tweedens, stel Levitikus 25:23: Geen grond mag permanent verkoop word nie, want die land behoort aan My. Julle is slegs vreemdelinge en bywoners by My. Die land ${ }^{2}$ behoort dus aan die Here (Fiensy 1991:3, 4; Fager 1993:31-33). As die land aan die Here behoort, is Israel die huurders en knegte van die Here. Talle praktyke demonstreer die onderliggende begrip (vgl bronne uit Hellenistiese en Romeinse tyd, naamlik 4 Esra 9:7; 12:34; 13:48; 2 Barug 40:2; 1 Henog 90:20; kyk ook Fiensy 1991:3, 4):

- Verdeling van die land deur die lot te werp (Num 26:55; Miga 2:5).

- Die opdrag om die oesreste aan die armes af te staan (Lev 19:9-10; 23:22; Deut 24:19-21). Jaarlikse tiendes en eerste vrugte moes aan die Here betaal word uit die opbrengste van die land en 'n tiende moes elke derde jaar aan die armes afgestaan word.

- Elke sewende jaar moes die grond 'n sabbatsrus ${ }^{3}$ gegee word en elke 50 jaar moes daar ' $n$ jubeljaar (hersteljaar) wees, waartydens alle skulde afgeskryf en alle grond aan hulle oorspronklike eienaars teruggegee word.

\footnotetext{
${ }^{2}$ Verwysings na die heilige land of die goeie land kom voor vanaf die tweede eeu $\vee C$ tot die tweede eeu n C, onder andere in Jubilee 13:2, 6; Wysheid van Salomo 13:3, 4, 7; Tobit 14:4, 5; 2 Barug 65:10; 71:1; 1 Henog 89:40; Kelim1:6-9; Mekilta Pisha I.

31 Makkabeërs 6:49, 53 verwys na die sabbatsjaar in die tweede tempel periode. Vergelyk verder die Mishna in die traktaat Shebiith (Klaagliedere van Rabbah, Proem; kyk Oppenheimer 1977:16).
} 
- Die konsep dat die land 'n heilige land is, hou verband met die gedagte dat God in die land woon en dat die land aan God gewy is (Num 35:24) (Fager 1993:116, 117).

Die kleinboerbesitter was verbind aan 'n stuk grond as onvervreembare erfenis en wat as sodanig erken was in die dorpe (vgl Philo Spec Leg 2:111; 2 Kon 21:3; Fiensy 1991:7). Buitestaanders wat die grond gevat het waarop die kleinboer gebly het, is beskou as indringers wat hulleself op die kleinboere afgeforseer het en aanspraak gemaak het op die oeste van die land. In so 'n geval is die relasionele aspek van grondbesit geminag. Die grondeienaar het teensinnig betaal aan bydraes soos belasting, rente, hereregte en ander verpligtings en uitgawes. Die gevoel teenoor die familie-erfgrond was 'n gevoel van lojaliteit. Die grond het net aan God behoort en dit is in "trust" aan Israel geleen as onvervreembare familieplase en kleinhoewes. Grond is volgens hierdie beskouing nie bedoel vir ekonomiese benutting nie, maar God het dit gegee om daarmee te oorleef (kyk Jub 45:13; Qumran 1 QS 10:8). Die tendens was dat al meer grond aan al hoe minder mense behoort het en dit op 'n besigheidsgrondslag (kyk diagram van Oakman 1991:158 en afd 2.4). Die meeste suksesvolle plase in die Romeinse Ryk het sowat 100 akker beslaan. Die grond is naastenby soos volg verdeel:

- Klein plase: 6 tot 50 akker.

- Medium grootte plase: 50 tot 315 akker.

- Groot plase: oor die 315 akker.

Die gemiddelde elite het 'n medium grootte plaas ${ }^{4}$ besit. ' $n$ Toenemende getal eienaars van medium grootte grond was afwesige landhere wat net in die opbrengs van hulle grond belang gestel het (Fiensy 1991:24). Die getuienis toon dat daar talle groot landgoed verspreid deur die land bestaan het, wat huurarbeid

\footnotetext{
${ }^{4}$ Fiensy (1991:21-73) het 'n omvattende ondersoek gedoen na die verskillende areas van Israel ten opsigte van die verdeling van grond en die grote van die plase. Verskeie antieke bronne is geraadpleeg vanaf Theophrastus (372-288 vC) tot by Josefus in die eerste eeu $\mathrm{nC}$ (vgl verder ook Historia Plantorum 9. 6:1-4).
} 
en slawe geverg het om te bewerk. Hierdie landgoed het gewissel van 50 tot 2500 akker (Fiensy 1991:60).

\subsection{Grondproduksie in relasie tot verskillende groepe mense}

\subsubsection{Dagloners}

Finley (1985:67) maak met reg die stelling "Absolute freedom is an idle dream

...." Wat is absolute vryheid - utopie of ' $n$ moontlikheid? Die vryheid van die mens het gewissel tussen twee pole. Die slaaf as eiendom en besittings aan die een kant, en die vrymens, wat vry en vrywilliglik optree. Nie een van bogenoemde moontlikhede het werklik bestaan nie. Tussen die twee pole is daar 'n hele reeks of spektrum van moontlikhede. 'n Mens besit of het ' $n$ gebrek aan regte, voorregte, eise en verantwoordelikhede in vele aspekte.

Dagloners en huurlinge was talryk in die eerste-eeuse Palestina. Die Rabbynse bronne gee vir ons 'n omvattende beskrywing van die sosioekonomiese toestande van die dagloners (kyk voetnotas 5 en 6). Landloses het hulleself alreeds voor die ballingskap, veral in oestyd, uitverhuur (vgl Rut 2:3). Maar die neiging om groot landgoed in Palestina te bekom moes hierdie klas mense se getalle verhoog het. Na gelang meer mense hulle grond verloor het, het hulle of huurders of dagloners geword. Nie alle dagloners was egter grondloos nie. Jonger seuns van 'n armoedige pa sou waarskynlik as dagloners gaan werk om die familie se inkomste aan te vul. Armoedige kleinboere met groot gesinne om te onderhou, moes waarskynlik ook gaan werk om hulle inkomste aan te vul (Klausner 1975:190; Fiensy 1991:85). Die dagloner wat geen grond besit het nie en totaal van sy loon afhanklik was, is pual jom genoem. Die sakir ${ }^{5}$ het 'n klein stukkie grond besit en sy inkomste aangevul met buitewerk. Hulle is vir ' $n$ vasgestelde periode gehuur. Die arbeiders kon vir enige denkbare werk aangewend word, byvoorbeeld om goedere rond te dra of as 'n wag. Vakmanne was beter daaraan toe as gewone dagloners, maar hulle

${ }^{5}$ BM 9:11; t. Sheb 5:21; t. BM 8:1; 10:2; t. Shab 17:27 (kyk Ben-David 1974:66). 
was in die minderheid. Die meeste het landbouwerk ${ }^{6}$ verrig soos byvoorbeeld ploeg, saai en oes.

Die lewe van die dagloner was fisies uiters veeleisend soos skelette wat by Qumran opgegrawe is, dit ook uitwys. Dit is moontlik dat mense ook na Qumran uitgewyk het as gevolg van beserings, armoede en siekte; meer as wat godsdiens hulle daarheen gedwing het (kyk Steckholl 1968:323-336). 'n Dagloon was sowat een dinarius/dragma (Matt 20:2, 9, 13), maar dit het gewissel na gelang van die soort werk wat vereis is. In die Tosefta en Babiloniese Talmud is daar ook baie getuienis dat die dagloners telkens uit hulle loon gekul is (vgl t BM $6: 15 ;$ b BB 87a). Verkeerde vergoeding, uitgestelde vergoeding en vergoeding vir 'n afgehandelde deel van die werk, was aan die orde van die dag (Fiensy 1991:86).

Die lewensstandaard van arbeiders het ook gewissel na gelang van die vaardigheidsgraad wat geverg is om hulle werk te doen. 'n Skrywer het byvoorbeeld, twee dinarii per dag verdien. Die grootte van sy gesin sou bepaal hoe ver hy met daardie geld sou kon kom. Die geskatte gemiddeld persone per gesin was ses tot nege mense. Die beraamde koste om ses mense aan die lewe te hou, beloop sowat 182 dinarii per jaar. Bykosse moes dan nog gevind word om die graan aan te vul wat met die geld gekoop is. Twee honderd dinarii word as die grenslyn vir armoede beskou. Indien iemand minder as dit geïn het, het hulle aanspraak gemaak op die armsorgvoorregte van daardie tyd (vgl Sperber 1970:1-15; Ben-David 1974:292; Fiensy 1991:87-89).

Die algemene lewenstandaard van die dagloners was maar laag. Hulle het waarskynlik meestal op die grens van verhongering gestaan. Ouers het dikwels self verhonger en hulle kos aan die kinders gegee. Solank die gesondheid gehou het en daar geen hongersnood in die land was nie, het die arbeider oorleef. Anders, het dit uiters moeilik met hulle gegaan (Fiensy 1991:88).

${ }^{6}$ T Maaserot 2:13, 15; t. BM 7:5, 6; BM 7:5; 7:7; 6:1; 8:8; Peah 5:5. 


\subsubsection{Slawe}

Finley (1985:62) dui 'n paradoks aan in die antieke verstaan van die posisie van 'n slaaf. Aan die een kant, is 'n slaaf die eiendom of besitting van sy of haar eienaar. Slawe varieer in waarde en kwaliteit. Slawe het gevlug en is soms hard geslaan. Slawe en diere was op dieselfde vlak. Wanneer hulle ander mense en hulle besittings skade berokken, het hulle eienaar die verantwoordelikheid gedra. Aan die ander kant, was slawe ook baie uniek. Die uniekheid as eiendom word soos volg beskryf: "first, slave women could and did produce children sired by freemen; second, slaves were human in the eyes of the gods, at least to the extent that their murder required some form of purification and that they were themselves involved in ritual acts, such as baptism" (Finley 1985:65).

Die inherente paradoks in antieke slawerny dui op 'n verskil in die wettiese status van die slawe. Dit dui op 'n verdere sosiale differensiasie by slawe (Finley 1985:65). Die slaaf het wel 'n toegewing van sy eienaar ontvang om besittings te hê en in transaksies met derde partye betrokke te raak. Finley (1985:64) beskryf bogenoemde vryheid onder die instelling van die peculliam. 'n Israeliet kon op een van drie maniere 'n slaaf word: Eerstens, as straf vir diefstal (Eks 22:1); tweedens, as die laaste uitweg vir iemand wat sy grond verloor het (Lev 25:39); en derdens, as betaling van 'n debiteur (Jes 50:1). Net nie-Jode het waarskynlik as oorlogsbuit slawe geword voor $70 \mathrm{nC}$. Die Israelitiese slaaf was tot slaafskap verdoem vanweë finansiële probleme en hulle moes teoreties in die sabbatsjaar vrygelaat word. Die Kanaänitiese slaaf was lewenslank 'n slaaf (Fiensy 1991:90).

Die Nuwe Testament verwys na landbouslawe in Matteus 13:27 wat kom rapporteer dat daar onkruid in die graan is. In Markus 12:2 word 'n slaaf gestuur om huur in te vorder. In Lukas 15:22 word melding gemaak van dagloners en slawe. Laasgenoemdes moes die vetgemaakte kalf slag. Slawerny het in elk geval nie in Palestina die omvang behaal as wat elders die geval was nie. Die slaaf is as eiendom beter behandel as die dagloners. Daar is geen werklike getuienis dat Hebreeuse slawe vrygelaat is gedurende die jubilee nie. Die slawe wat deur Simon Bar-Giora vrygelaat is, het dadelik die opstand ondersteun en 
was desperate mense wat waarskynlik nie verwag het om in 'n jubilee vrygelaat te word nie (Josefus BJ 4:508). Fiensy (1991:92) beweer dat op grond van die stilswye, asook duidelike bewyse, dat die jubileewette ${ }^{7}$ toenemend geïgnoreer is en dat Hebreeuse slawe waarskynlik nie vrygelaat is nie. Die nie-Joodse slaaf was vir altyd tot slaafskap verdoem en is in Palestina waarskynlik tydens die Hasmonese oorwinnings-togte en Herodus se oorlog teen die Nabateërs bekom. Vreemdelingslawe kon egter ook op die oop mark in Palestina gekoop word.

Sommige van die vreemdelingslawe is besny en gedoop, om van hulle proseliete $^{8}$ te maak (Fiensy 1991:92).

Volgens Koester (1994:535-546) kan slawe egter nie aanspraak maak op opstanding en apotheose (vergoddeliking) nie. Dit is waarskynlik een van die redes waarom Paulus en ander sendelinge se boodskap so vinnig versprei het. Slawe het 'n groot deel van die Mediterreense gebied uitgemaak (45\%). By Christene het hulle gehoor dat ook hulle (en nie net die elite nie) "onsterflikheid" en 'n lewe saam met die gode (in hierdie geval God) as 'n gawe of genade ontvang.

\subsubsection{Kleinboere}

Wie is die kleinboere? Volgens De Ste'Croix (1981:210; vgl Fiensy 1991:vi) is kleinboere:

\footnotetext{
7 Die vraag kan steeds gevra word of die kwytskelding van skuld en vrylating van slawe toegepas is. Josefus (Ant 3:283) het byvoorbeeld drie hipotetiese voorbeelde genoem van toestande waaronder die grondeienaar die grond kon behou of verloor (kyk Fiensy 1991:10). Ons lees te veel van boewery, dagloners en kleinboere as huurders om te kan aflei dat die jubileewette toegepas is. Tekste van beide die Talmud (j. Sheb 10:4; b. Arak 32b-33) en van die Tannaïtiese midrash (Sifra; Behor Sinai 7:1) bevestig dat die jubileewette nie in die tweede tempel periode toegepas is nie. Die hunkering na die toepassing van die jubileewette in die Herodiaanse tydperk het baie sterk geleef (vgl 11 Q Melgisedek).

${ }^{8}$ Daar was drie stappe om tot die Israelitiese geloof toe te tree. Verskillende soorte proseliete word beskryf, waarvan die bekendste die "liefdesproseliete" was, dit is diegene wat met 'n Israeliet wou trou. Daarteenoor, was die "leeuproseliete" wat uit vrees vir die leeus, Israeliete geword het, maar nog steeds afgode gedien het (kyk Van Aarde 1994:166, 167). Die volgende Rabbynse literatuur verwys na proseliete, naamlik b. Shabb 137b; b. Yeb 48b; Mekkilta. Eks 20:10.
} 
- bestaansboere wat hulleself in stand gehou het met die vrugte van hulle eie arbeid;

- hulle kon vryboere, huurders, dagloners of landbouslawe gewees het;

- hulle het meestal hulle eie grond as 'n familie-eenheid bewerk;

- hulle het kollektief meer geproduseer as wat hulleself nodig gehad het en met die surplus het hulle die eliteklas onderhou, onder wie se gesag hulle tot 'n mate gestaan het.

Die hoër klas bestaansboer of kleinboer is diegene wat geen buite inkomste vir oorlewing nodig gehad het nie (vgl Forster 1965). Hulle het genoeg grond besit om vir hulle families te sorg. Die laer klas bestaansboer het wel van die grond se opbrengs gelewe, maar moes 'n byverdienste vind. Die kleinboere wat grond besit het, is belangrik omdat hulle ook in ' $\mathrm{n}$ sekere sin as belastingbetalers in diens van die elite gestaan het. Met die belastings het Herodus stede gebou en geskenke uitgedeel. Hulle het ook die priesterstand grootliks met hulle belastings onderhou. Die huurders kon in moeilike tye staatmaak op die landheer om hulle by te staan, maar die kleinboer moes maar self die laste dra. Die kleinboer se eerste nagmerrie was altyd skuld (De Ste'Croix 1981:214; Fiensy 1991:93) en broodtekort. Kleinboere was meestal op die rand van onveiligheid vanweë die feit dat hulle grond klein was, die mensgemaakte en natuurkatastrofes en die belastingstelsel.

Volgens gebruik is die helfte van 'n persoon se grond jaarliks om die beurt onbewerk gelaat en daarom is omtrent 17 akker grond nodig om in 'n gesin se graanbehoeftes van drie kor per jaar te voorsien. Volgens Fiensy (1991:93) is dit egter net spekulasie, omdat die kleinboere ook olywe en wingerde geplant het. Sommige het graan tussen die olywe gesaai. Meeste van die grond was nie meer as ses akker groot gewees nie. Sulke kleinhoewes kon slegs een kor opbrengste lewer, wat een familie vir een derde van die jaar kon voed. Die meeste kleinboere moes elders ' $n$ ekstra inkomste verdien, byvoorbeeld om as arbeider te gaan werk soek, jag, visvang, veeboerdery, kleinvee of om 'n rower te word (vgl Josefus Antiquities 16:271; 18:274; Oakman 1986:58-72; Fiensy 1991:96). Fiensy (1991:97) betoog dat geen gefundeerde afleiding oor die 
lewenspeil van die mense gemaak kan word nie, omdat ons te min van hulle weet. Die klassifikasie en afleidings wat gemaak is op beendere wat opgegrawe is, is spekulatief en moeilik. ' $n$ Ander tipe ondersoek is om afleidings te maak oor die gebrek aan voeding, deur die ratio kinders teenoor grootmense wat in die grafte gevind word en die patologie van sulke kinders. Kinders was gouer die slagoffers van wanvoeding as volwassenes (Fiensy 1991:97). Die slotsom van hierdie ondersoek was dat wanvoeding of siekte die oorsaak is van kindersterftes. Die armer sosiale klasse in Palestina in die Romeinse Ryk moes knaend honger gewees het.

\subsection{Grond as die oorsaak van stryd}

$\mathrm{Na}$ aanleiding van die oorsig van die eerste-eeuse ekonomiese situasie, kan die vraag gevra word: Hoe het Jesus die probleem van wanverspreiding van of differensiële beheer oor essensiële ekonomiese goedere aangespreek? Die primêre ekonomiese goedere was grond. Veranderende vorme van grondbesit en die steurende effek van skuld is die natuurlike vertrekpunt van hierdie ondersoek. Ander goedere soos voedsel, klere, huisvesting, en geld is indirek deel van die ondersoek van die Jesus-materiaal ${ }^{9}$ in verband met rykdom en mededeelsaamheid (sharing).

Groot konflik oor grondbesit het in Israel ontstaan met die koms van die Grieke en Romeine. Hierdie stryd oor grondbesit het uitgeloop op die Joodse oorlog. Dit was 'n stryd om die gebruik van die grond en die verspreiding van die opbrengs. Grond was die primêre produksie faktor in die agrariese gemeenskap. Toegang tot grond is noodsaaklik vir oorlewing. Het Jesus enige reaksie geformuleer ten opsigte van die probleem van inheemse verlies van grond-eienaarskap? Hoe hou Jesus se houding en intensies oor eienaarskap

${ }^{9}$ Oakman (1986), in Jesus and the economic questions of his day, maak nie genoegsame onderskeid tussen die voor-Pase Jesus en die na-Pase geïnterpreteerde Jesus nie. Volgens Van Aarde (1986:10-16) se transparantteorie het Matteus twee vertellyne wat in analogie tot mekaar staan (vgl afdeling 2.1.8.1.3 en endnotas in hoofstuk 2). Die Jesus-periode is getranspareer na die vroeë kerk-periode, sodat die twee wêrelde tegelykertyd in die evangelie opgeneem is. ' $n$ Evangelie vertel dus van mense en dinge vanuit ('n) vroeëre periode(s), terwyl die latere periode waarin die vertelling finaal gekommunikeer het, in die vertelde wêreld deursigtig is (Van Aarde 1986:10). 
verband met die verkondiging van die koninkryk van God? Sommige woorde van Jesus stel voor dat Jesus grond beskou het as 'n oorsaak van stryd. Jesus het Homself nie as regter beskou in eiendomsdispute nie. Sommige gelykenisse fokus op die probleem van grondbesit. Markus 12:1-12 skets die soort verhoudings wat ontstaan het deur landheerskappy in agrariese konteks. Van die landbouers het moorddadig begin word in hulle strewe na eienaarskap (Oakman 1986:144). Hierdie soort van vyandigheid teenoor die besittersklas was tipies van die eerste-eeuse Palestynse sosiale verhoudings. Jesus toon geen spesifieke simpatie met die besitters se optrede nie (Mark 12:9). Lukas 13:6-9 verwys wel na die tema van stryd. Die gelykenis verwys na 'n man wat 'n vyeboom geplant het (waarskynlik 'n afwesige grondeienaar), wat de facto die besitter van die boord is. Vir Oakman (1986:145) is die punt wat die gelykenis maak, dat die werklike eienaar, die een wat die lande bewerk en omgee vir die boorde, bereid is om baie op te offer om produksie uit 'n onproduktiewe boom te kry. As die boom uitgehaal word, dan sal hy weer 3, 4 of 5 jaar moet wag vir die volgende aanplanting. Jesus se simpatie lê by die landbouer wat die vyeboom versorg. Die eienaar de iure, stel waarskynlik net belang in die onmiddelike profyt van die boord, moontlik onbewus van wat die kostes van die profyt sal wees.

\subsection{Skuld en kwytskelding van skuld}

Baie van die Judeërs in Jesus se tyd het onder 'n toenemende skuldlas gewerk. Die probleem van skuld het die kwaliteit van verhoudings tussen die besittersklas van die eerste-eeuse Palestina en hulle wat gedwing is om te huur of loonarbeiders te word, vertroebel. Skuld was een van die meganismes waardeur die rykes al ryker ${ }^{10}$ geword het en die armes al armer (vgl Goodman 1982:417427; Kee et al 1997:378-381). Deur skuld is die eienaarskap van die erfgrond van die kleinboere afgerokkel. Die regte van die krediteure is 'n ander

10 Kyk Harvey (1982) oor die verhouding tussen arbeiders en hulle loon en Malina (1987) ten opsigte van ryk en arm in die Nuwe Testament. 
manifestasie van die ongevoelige egoïsme van die ryk elite wat waarborge geëis het, waarborge ten koste van die minderbevoorregtes.

Skuld het 'n groot rol gespeel in die versteurde sosiale verhoudings van die tyd van Jesus. Daarom het Jesus die vertakkings en die geleenthede van hierdie probleem ontgin (vgl bv Matt 18:12-35; die gelykenis van die onvergewensgesinde amptenaar). In Matteus 18:12-35 word die reaksie van die vergeefdes gemeet deur die reaksie van liefde teenoor die genadige krediteur. Die reaksie is die tertium comparationis. Die rigting van die reaksie teenoor die genadige krediteur of genade teenoor die debiteure moenie die onderliggende punt van reaksie verhinder, wat vergelykbaar is met die ervaring van vergifnis of kwytskelding nie. Die gunstige reaksie op die goedgunstige vergifnis is ook die fokus van die bestuurder se optrede in Lukas 16:1-8. Jesus het die bestuurder (oikonomos is 'n slaaf) wat sy eienaar benadeel het om sy eie situasie te bevoordeel, se optrede geprys. Hierdie onregverdige bestuurder is deur die eienaar weggejaag. Sy lot was 'n onteiende arbeider of bedelaar. Hierdie bemiddelaars (oikonomos) dwing 'n onderdrukkende agrariese sosiale orde af, en hulle is deur die kleinboere gehaat. Die politieke sluheid van die bestuurder is vanuit 'n agrariese oogpunt verstaanbaar. Deur die debiteure se skuld kwyt te skeld, het die oikonomos vir homself positiewe alternatiewe moontlik gemaak (Oakman 1986:151). Oakman (1991:158) gee die volgende diagramatiese voorstelling van hoe kleinboere verkneg is deur skuld tot op sodanige punt waar hulle hulle grond verloor het: 


\section{HOE KLEINBOERE HULLE GROND VERLOOR HET DEUR SKULD}

\section{ELITE SE BELANGE}

Politieke mag verkry deur afhanklikes voortdurend te verskuld

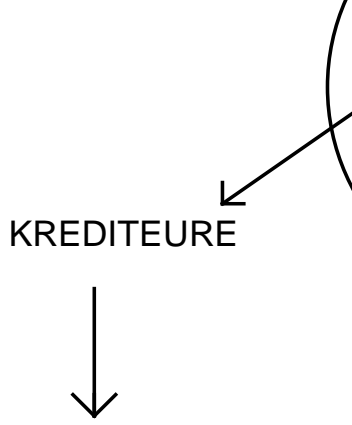

Lenings op grond toegestaan en skuldkontrakte afdwingbaar deur howe (beheer deur elite)

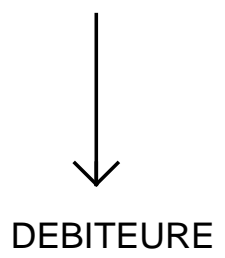

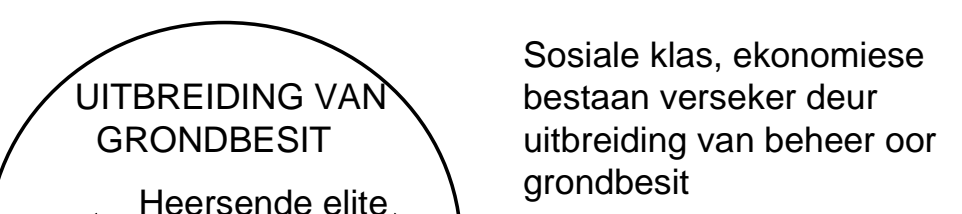

Kapitaal' beskikbaar deur
handel

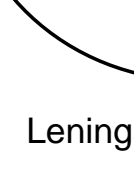

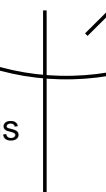

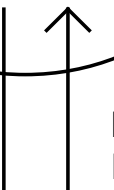

Belasting
Rente

Godsdienstige Konsentrasie van grond tiendes

Betaling van lenings deur nie betaling van skuld en afdwing van grondwaarborge

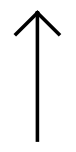

HUURDERS

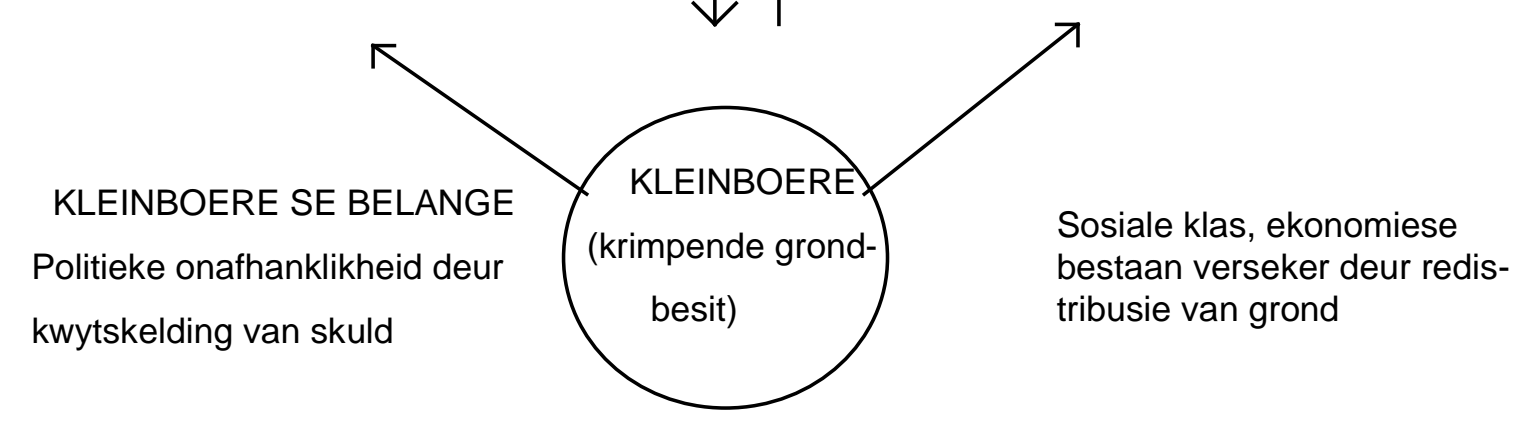

Hoekom het Jesus die oneerlike bestuurder geprys? Het Jesus die onderdrukte kleinboere se kant gekies teen die rykes? Nee, hierdie gelykenis is gemik teen die rykes self. Die bestuurder se vrygewigheid is lofwaardig. Dit is ' $n$ vrygewigheid wat gemotiveer is deur selfbelange, maar wat prysenswaardige gevolge het. Hierdie vrygewigheid verlig die onderdrukkende omstandighede (die eksploiterende elite teenoor die onderdrukte kleinboere) en skep ook die basis vir 'n nuwe verhouding met die kleinboere. 
Gregory (1975:74; vgl Oakman 1986:152) glo dat daar in die dorpe van kleinboere waar ekonomiese ongelykhede bestaan, gedink is dat hulle wat baie het, ook moet deel met dié wat nie baie het nie. Die rykes is verantwoordelik vir die wyer sosiale orde. As die ongelykhede te groot word, sal die sosiale orde in duie stort. Daarom moet hulle nie te ryk word nie. Die verwagting om te gee is 'n morele verpligting teenoor die sosiale orde. Hierdie vertellings van Jesus sinspeel almal sterk op hierdie verwagting om te gee. Genade is onvoorwaardelik. Vergifnis, daarteenoor, lê 'n groot verantwoordelikheid op die ontvangers daarvan. Die ontvangers is verantwoordelik van wanneer en hoe hulle hulle nuwe verpligting sal vervul. Hulle is onder 'n algemene, maar onvoorwaardelike, verpligting by die ervaring van kwytskelding van skuld.

Die kwytskelding van skuld word duidelik na vore gebring deur die Onse Vader-gebed. Die Griekse woord aphiemi dui beide op die kwytskelding van skuld en op 'n metafoor wat na vergewing verwys. Hierdie woorde het dus beide die betekenis van sonde of van skuld (Oakman 1986:153). Vergifnis het 'n vertikale aspek, sowel as 'n horisontale aspek. Vertikaal kan vergifnis nie anders verstaan word as vergifnis van oortredings (skulde = ongehoorsaamheid, sondes) teenoor God. In die konteks van horisontale verhouding tot die naaste metaforiseer Matteus skuld om alle soorte sosiale verpligtings te dek.

Hoe het Jesus die woorde in hierdie vers (Matt 6:12) verstaan? Wat het dit beteken binne die konteks van Jesus se bediening? Eerstens, moet daar gewys word op die parallellisme wat een of ander verband suggereer tussen die klein vergifnis/kwytskelding deur Jesus se dissipels en die groot vergifnis/ kwytskelding wat God alleen kan gee. Die klein vergifnis hou verband met werklike skuld, maar kan ook uitgebrei word na morele skuld. Jesus het primêr gepleit vir kwytskelding van aardse bande wat deur skuld veroorsaak is. Die probleem van skuld, die onderdrukking van die mense van Palestina is so groot dat dit slegs deur die mag van God doeltreffend verbreek kan word. Selfs 'n eskatologiese verstaan van die teks moet rekening hou met hierdie materiële verwagtings (Oakman 1986:154). 
Tweedens, is daar ' $n$ sinonieme parallelisme tussen die vergifnis van skuld en die voorafgaande vers van die daaglikse brood. Skuld is 'n bedreiging vir die beskikbaarheid van daaglikse brood. Die petisie vir daaglikse brood is terselfdertyd ' $n$ petisie vir 'n sosiale orde wat die basiese menslike behoeftes sal voorsien op 'n gereelde en konstante wyse. Skuld verbreek die vermoë van 'n sosiale orde om daaglikse brood te voorsien. God word versoek om die onderdrukkende mag van skuld in mense se lewens te verwyder (Oakman 1986:155). Die voorgestelde interpretasie word op die basis van 'n ander oorweging aangemoedig. Jesus se bediening spreek spesifiek die landloses aan, hulle wat om een of ander rede gedwing is tot bedelary, prostitusie, tollenaarskap, of enige beroep wat nie direk te make het met die bewerking van grond nie. Baie van hierdie mense het die realiteit van skuld geken. Hulle kon dalk nie ontslae raak van die skuld nie en is as gevolg daarvan geostraseer uit die normale sosiale bande. Die Onse Vader-gebed spreek met bogenoemde verse die mense se behoeftes direk aan. Oakman (1986) en Crosby (1988) stem dus saam in verband met die interpretasie van die Onse Vader-gebed.

Die relasie tussen die broodgebrek en skuld as die horison waarteen die brood en vergifnis petisies verstaan word, asook die sosiologiese oorwegings oor die godsdienstige belange wat aan die werk is in die bediening van Jesus, bevraagteken die vergeestelikte interpretasies van die gebed van Jesus wat alreeds in die sinoptiese tradisie begin. Hierdie interpretasies verstaan die versoek tot God om vergifnis net in morele terme. Die beoefening van vergifnis/kwytskelding op aarde is verbind a minori ad maius aan die radikale vergifnis/kwytskelding met die koms van die koninkryk van God: as Jesus en die dissipels hierdie kwytskelding nou kan beoefen, hoeveel te meer sal God se kwytskelding nie bevry wanneer dit gebeur nie. Jesus verkondig kwytskelding van onderdrukkende ekonomiese laste, maar bepleit 'n morele verpligting tot 'n nuwe sosiale gedrag van vergifnis (Oakman 1986:156).

\subsection{Rykdom en kritiek op rykdom}

Matteus het waarskynlik geskryf vir relatief welvarende Christene. Matteus se unieke materiaal (M) het min vyandigheid teenoor rykdom (Oakman 1986:157). 
Lukas daarteenoor is die felste in sy kritiek teenoor rykdom. Meadland (1980:9091; vgl Oakman 1986:157) glo dat daar 'n tendens by die eerste Christene in landelike Palestina was om skerp kritiek te lewer teen rykdom en die rykes. Hierdie tendens is veral aangewakker tydens die hongersnood onder Claudius, toe die wedersydse hulpverlening sisteem van die Palestynse kerk nie genoegsaam was om die krisis te hanteer nie. Daar kan dus aanvaar word dat Jesus nie skerp kritiek teen die rykes of rykdom as sodanig gehad het nie. Jesus se kritiek het nie skerp grense getrek nie. Jesus en die dissipels het al hulle besittings en eiendom prysgegee vir die koninkryk van God en hulle het die lewenstyl gehad van die wandelende predikers (Oakman 1986:157).

Daarteenoor, wys Hengel (1974:23, 26; vgl Oakman 1986:158) op die kontradiksie in die Jesus-tradisie tussen ' $n$ radikale kritiek op eiendom en Jesus se vrye houding teenoor eiendom. Jesus is minder krities teenoor rykdom as die latere tradisies in die sinoptiese evangelies. Die kontradiksie is duidelik in die uitsprake (kritiek teen rykdom) en die narratiewe materiaal (Jesus wat saam met ryk tollenaars eet en drink).

Die vertelling van die ryk man in Markus 10:17-22 onderstreep die morele verleentheid van gedeelde lojaliteit. Hierdie man is nie vry om die geregtigheid van God se koninkryk te doen nie. Maar nogtans het Jesus die mens liefgehad en nie gehaat nie. Die materiële dinge word nie per se gedegradeer nie. 'n Sosiale orde word gekritiseer, persoonlike eiendom of 'n persoonlike hoop wat die doel het om selfgenoegsaamheid te verseker. Waarskynlik het Jesus die vernietiging van privaateiendom gevisualiseer, soos wat voorgestel is by grondbesit (Oakman 1986:159). Selfgenoegsaamheid was die etos van die ryk elite en Jesus het hierdie etos op verkillende maniere aangeval. As die man al sy goed prys gegee het, hoe sou hy kon voortbestaan? Jesus toon vyandigheid teenoor persoonlike rykdom, maar nie teenoor die ryk persoon nie. Jesus onderskei tussen die sondaar en die sonde. Jesus ontken nie die gebruik van materiële goedere nie. Die goedere van die lewe is daar om gebruik te word. Jesus was nie 'n askeet nie, Jesus het nóg armoede nóg Mammon aanbid 
(Oakman 1986:159). Deur die hoop op die materiële goedere te stel, kom die aanslag van die bose. Wat sal gebeur as almal die rykdom deel?

Die probleem met Oakman (1986) se verstaan van Jesus en rykdom is as gevolg van 'n gebrek aan eerstens 'n duidelike sosiaal-wetenskaplike model as verwysingsraamwerk van die eerste-eeuse Mediterreense samelewing, asook die sosiale stratifikasie van die eerste-eeuse Palestina. Van Aarde (1988:839) wys daarop dat die begrip sosiaal-veragtes verskillende betekenisse kan hê binne verskillende sosiale verbande as deelwêrelde. Sosiaal-veragtes is dus meer as net die ekonomiese armes of die politieke onderdruktes, soos in die Marxistiese verstaan van die samelewing. Die landvolk was mense soos bedelaars, melaatses, tollenaars, diewe, bedrieërs, egbrekers, siekes, blindes, ongelowiges ensovoorts. Van Aarde (1988:843) verstaan armes binne die eerste-eeuse Mediterreense konteks as mense wat nie hulle posisie kon handhaaf as ongelukkige omstandighede hulle oorval het nie. 'n Verskeidenheid van omstandighede kon aanleiding gee tot armoede, naamlik skuld, ballingskap in 'n vreemde land, siekte, dood van 'n eggenoot of een of ander persoonlike of fisiese gebrek.

Wat die "armes" betref, is dit duidelik dat hulle nie beskou moet word as 'n sosiaal gestruktureerde klas nie. Daarom is dagloners, plattelanders sonder grondbesit, bedelaars ensovoorts nie op sigself die "armes" nie. Die "armes" is nie as sodanig 'n ekonomiese kategorie nie. Die alternatief van die "arme" is derhalwe ook nie noodwendig die "ryke" nie.

(Van Aarde 1988:843)

\section{DIE SOSIALE STRUKTUUR VAN PALESTINA}

\subsection{Inleiding}

Fiensy (1991:155) wys belangrike flaters uit wat vermy moet word in die beskrywing van die sosiale struktuur van Palestina. Die flaters wat vermy moet word, is om nie die sosiale struktuur te verwar met die godsdienstige 
groeperings, asof elke Judeër aan een van die bekende godsdientige groepe behoort het nie. Ook die Rabbynse wysgere mag nie as 'n sosiale groep beskryf word nie, want onder hulle was ryk en arm, priesters en gewone mense, hoë staatsamptenare en dagloners. Die am ha-aretz kan ook nie as 'n sosiale klas hanteer word nie. Hoewel talle van hulle arm was, was sommige rykes ook so genoem (veral in die Mishna tydperk). Die Rabbis het die term net in godsdienstige sin gebruik om te onderskei tussen Rabbynse groepe en ander mense.

Verder moet moderne sosiologiese teorieë wat ontwerp is vir industriële gemeenskappe, krities hanteer word. 'n Model uit die sosiologies-antropologiese wêreld wat benut kan word, is saamgestel uit die teorieë van G E Lenski (1966) en G Alföldy (1986). Lenski (1997) kombineer die insig van die funksionaliste en teorieë oor klassekonflik. Lenski hanteer die gemeenskappe volgens die antropologiese klassifikasie van kultuurontwikkeling, naamlik bendes, stamgroepe, agrariese gemeenskappe en industriële gemeenskappe. Alföldy se bydrae is die onderskeiding tussen die hoër en lae klasse, asook tussen die platteland en die stadslewe (Fiensy 1991:156).

\subsubsection{Sosiale stratifikasie}

Daar het 'n groot sosiale en ekonomiese gaping tussen die hoër en laer klasse bestaan. Die hoër deel van die grafiek het uit die minderheid bestaan (sowat 1\%). Die hoër klasse was almal stedelinge wie se rykdom uit die grond gekom het en hulle het die een helfte van die agrariese gemeenskap uitgemaak (nie getalle gewys nie!) en die sogenoemde Groot Tradisie verteenwoordig. Die ander deel van die agrariese gemeenskap was die plattelandse massas wat die Klein Tradisie gehandhaaf het. Die moderne ekonomiese teorieë, veral die Marxistiese teorie, word gebou op die klasse-onderskeid wat gegrond is op ekonomie (Van Aarde 1994:91). Sodanige werkwyse is gegrond op reduksionistiese ${ }^{11}$ perspektief van sosiale stratifikasie en die ekonomie. Van Aarde (1994:91) waarsku verder teen die anakronistiese toepassing van die begrip klas, soos onder andere by Karl Marx beskryf, op die eksegese van

\footnotetext{
${ }^{11}$ Met reduksionisties word verstaan dat die vier sosiale instellings gereduseer word tot net politiek en ekonomie en dat die ekonomie nie bestudeer word in relasie met die ander drie sosiale instellings nie (kyk Van Aarde 1991:6, 7; Van Eck 1995:10).
} 
Bybelse tekste. Die dialekties-historiese materialisme van Karl Marx toon die wyse aan waarop die moderne sosio-ekonomiese hiërargieë in die industriële samelewing georganiseer en ideologies bepaal was.

Om die verskynsel van die hiërargieë van klasse in die samelewing egter slegs in terme van materialistiese idees te verstaan, en boonop vanuit die perspektief dat die ekonomie die mees dominante dryfkrag agter alle sosiale interaksies is, kan aan die tegnokratiese era van die twintigste eeu reg geskied, maar beslis nie aan die gevorderde agrariese samelewing van die eerste-eeuse Mediterreense sosiale konteks nie.

(Van Aarde 1994:91)

Sosiale stratifikasie is vandag nie meer 'n enkelvoudige saak nie, maar 'n multidimensionele fenomeen. Daar is 'n verskeidenheid van dimensies waaraan 'n individu of groep se rang gemeet kan of moet word. Die vroeë Christene se sosiale status kan nie met 'n enkelvoudige begrip beskryf word nie. Die enkelvoudige beskrywing van die vroeë Christene se sosiale status ${ }^{12}$ as middelklas is vaag en misleidend. Dit is vaag omdat dit die multi-dimensionaliteit van stratifikasie ignoreer. Dit is misleidend (anakronisties - GV) omdat dit veronderstel dat daar 'n ooreenkoms is tussen die antieke Griekse stad en die middelklas van die moderne industriële samelewing (kyk Meeks 1983:54).

Finley (1985:45-50) gee 'n duidelike definisie van die kategoriëe van sosiale divisies en toon die noodsaaklikheid van sodanige onderskeid aan. Van Aarde (1994:91) stel dat klas en status in die verlede en in die hede die oorsaak vir stratifikasie in die samelewing was en steeds is. Die grense tussen groep(e) en klasse is baie vaag. Lenski (1991:217; kyk ook Duling 1992:105; Van Aarde 1994:91) toon in sy diagram van die sosiale stratifikasie van die (eerste-eeuse Joodse) gevorderde agrariese samelewing aan, dat mag, prestige en rykdom nie bepaal word deur diegene wat meer of minder (of geen) middele besit nie. Die drie faktore was nie altyd op alle plekke en te alle tye ewe belangrik nie. In klein

12 Smith (1980), Blasi (1986) en Stark (1986) gee 'n volledige bespreking van die sosiale status van die vroeë Christene, asook omvattende literatuurverwysings. 
gemeenskappe binne 'n gevorderde agrariese (advanced agrarian) samelewing speel prestige 'n groter rol, maar in groot gemeenskappe is rykdom weer meer bepalend. Van Aarde (1994:91) beskryf die ongelykheid soos volg: Ongelykheid in agrariese samelewings is veral deur 'n ongelykheid met betrekking tot eer/prestige bepaal en dit het weer op 'n afgeleide wyse 'n ongelykheid in mag en rykdom veroorsaak.

\subsubsection{Sosiale onderskeid tussen orde, klas en status}

Die drie kategorieë van sosiale onderskeiding is orde of stande, klas en status. Finley (1985:45; vgl ook Meeks 1983:53) definieer die eerste kategorie, naamlik 'n orde as ' $n$ juridies gedefineerde groep binne die bevolking wat formele voordele en kwytskeldings op 'n verskeidenheid terreine gehad het, naamlik regering, militêr, legalisties, ekonomies, godsdienstig, huwelik en hiërargiese relasie teenoor ander ordes. Lidmaatskap word ideaal gesproke, oorgeërf.

Die simplistiese tweedeling is nie staties nie, omdat die gemeenskap 'n dinamiese organisasie is, soos die Romeinse samelewing dan ook was. Die vraag was net hoe 'n patriargale huis sonder 'n manlike erfgenaam vervang moet word. In die laat tweede eeu $v$ C was die ordes onvoldoende as ' $n$ integrerende instelling, maar terselfdertyd was die tradisie van ordes te sterk om geïgnoreer te word. Die twee belangrikste en lank durendste ordes in die latere Romeinse Ryk is die senatore en die ridders. Die tweede kategorie van sosiale onderskeid is die status. In die latere Romeinse Ryk het die adelstand/nobility aan die hoof gestaan van die hiërargie. Die status is die mees algemene en bruikbare sosiale klassifikasie waardeur 'n duidelik beeld gevorm kan word van die sosiale stratifikasie in die Grieks-Romeinse stede. Die adelstand het geen juridiese gronde gehad nie, maar was beperk, de facto, tot daardie families wat aanspraak kon maak op 'n konsul, uit die verlede of die hede. 'n Duidelike definisie vir status ontbreek by beide Finley (1985:49-51) en by Meeks (1983:54). Soos reeds bo gemeld, is 'n individu of groep se status nie 'n enkelvoudige konsep nie. Die sosiale vlak moet gemeet word in terme van al die relevante dimensies. 
Meeks (1983:54) verwys met reg na die sosiale stratifikasie as 'n multidimensionele fenomeen. Buiten die verskeie dimensies, moet verskeie ander faktore ook in ag geneem word. Eerstens, dra nie alle dimensies dieselfde gewig nie. Tweedens, word die gewig van elke dimensie bepaal deur wie die meting doen. En laastens, vorm die mate van korrelasie tussen individue se onderskeie range ' $n$ ander soort veranderlike wat ander mense se evaluering van hulle en hulle eie evaluering van hulleself beïnvloed. Laasgenoemde dimensie word status konsistensie, status kongruensie of status kristallisasie genoem. Sosiale status is in agrariese samelewings baie belangriker as klas. Sosiale status het in 'n agrariese samelewing (baie meer as in vandag se geïndustrialiseerde konteks) tot mag en rykdom gelei (kyk Van Aarde 1994:91). Status het gewoonlik langdurige politieke mag en daarmee saam rykdom aan die hand gewerk. Van Aarde (1994:91) beskryf die mag van die aristokrasie gegrond op hulle sosiale status soos volg:

Die wyse waarop die aristokrasie (adelklas) in 'n agrariese samelewing spontaan gevorm en gefunksioneer het, het die aard van die klassesisteem in die eerste-eeuse Mediterreense wêreld bepaal. In terme van die aristokrasie het geboortelike herkoms en familiale belange 'n sterker ideologiese rol vervul as wat sigbaar was op die oppervlak van die samelewing wat deur wette en regulasies georden is. As sodanig het die aristokrasie as groep nie enige politieke mag of wettige status in die agrariese samelewing gehad nie. Die mag wat hulle besit het, is daaraan toe te skryf dat hulle ' $n$ bepaalde statusgroep was.

Die laaste kategorie van sosiale stratifikasie is die klas. Finley (1985:48-50) sowel as Meeks (1983:53) is baie vaag in 'n pertinente definisie van klas. Meeks (1983:53) definieer klas as: ... it refers almost exclusively to income level, with perhaps the added qualification of the way in wich income is obtained (my kursivering). Onderskeid word gemaak tussen die juridies gedefinieerde groepe (dit word ordes genoem) en nie-juridies gedefinieerde groepe (dit word klas genoem). Die genoemde geleerdes waarsku met reg op 'n eensydige persepsie van wat ' $n$ klas is. Vir Karl Marx word klas bepaal deur die relasie tot die 
produksiemiddele, op grond waarvan drie groepe onderskei word: grondeienaars, kapitaliste en werkers.

Max Weber (1922) definieer klas ook in relasie tot ekonomiese terme, maar gedefinieer deur die mark (vgl Robertson 1987:1-11). Beide Karl Marx en Max Weber se definisies definieer nie die antieke samelewing korrek nie, omdat dit groepe saam groepeer wat in die antieke tyd pertinent onderskei behoort te word (Meeks 1983:53). Bogenoemde kritiese opmerkings in verband met sosiale stratifikasie bepaal die rigting wat ingeslaan behoort te word in die beskrywing van die ekonomiese omstandighede van die antieke tyd. Lenski (1991:217; vgl ook Fiensy 1991:158-165) se grafiek sal vervolgens breedvoerig uiteengesit word. Verder sal die sosiale stratifikasie, na aanleiding van Vledder (1994:511522) se navorsing, toegepas word op die Matteus-evangelie.

\subsection{Die stedelike elite}

Die Matteus-gemeenskap kan beskou word as 'n gevorderde agrariese gemeenskap (Vledder 1994:520). Die stedelike elite kan gedifferensieer word in twee groepe, naamlik die regeerder en die regerende klasse (vgl Lenski 1966:219, 243; Saldarini 1988:40-41; contra Rohrbaugh 1993a:383). Die hoër klasse was beide polities invloedryk en ekonomies baie ryk, met hulle status wat op rykdom berus het. Rome het die beheer van 'n land altyd aan die rykes toevertrou en daarom was rykdom en 'n beherende posisie sinoniem (kyk Saldarini 1988a:40). Bo aan die toppunt van die sosiale grafiek van daardie tyd het die keiser of die keiser se afhanklike kliënte-koning plaasgeneem (Herodus die Grote, Agrippa I en Agrippa II), die prokurator of die tetrarg of etnarg (Argelaos, Antipas, Fillippus). Hulle het alle leiers in sowel rykdom as in politieke mag oortref. Die beheer van die ekonomiese en politieke sisteme is gelegitimeer deur die godsdienstige en opvoedkundige burokrasie (kyk Rohrbaugh 1993b:12). Bogenoemde ryk heersers het hulle hoë staatsamptenare en vriende met groot

skenkings bederf, die aanstelling van die hoëpriesters beheer, die weermag aangevoer en belastings gehef, daarom was hulle mag selfs oor ander adel groepe baie omvangryk (Saldarini 1988a:40; 1988b:200; Fiensy 1991:156; 157; 
Lenski 1991:205-209; kyk ook Duling:1992:102; Rohrbaugh 1993a:383; Van Aarde 1993:532). Vledder $(1994: 513,514)$ gee 'n volledige tabel van die lede van die stedelike elite in die Matteus-evangelie.

\subsubsection{Die Herodiane}

Hulle was die uitgebreide familie van Herodus en hulle nageslag, wie se geërfde eiendom aansienlik groot was. Ingeslote by die groep was ook talle hoë amptenare aan wie Herodus (en die twee Agrippas) groot landgoedere geskenk het (Josefus Antiquities 15:185; 17:55; 17:225; War 1:576; 2:21). Die Herodiane het meestal in die stede gewoon waar hulle paleise vir hulleself gebou het (Josefus War 5:176-183; 2:426; Vita 46, 64-67). Volgens Rohrbaugh (1988a:383) was dit versterkte, sentrale areas van die stede met hoë mure, wat hulle fisies en sosiaal geïsoleer het van die samelewing. Herodus en sy nageslag het paleise gebou wat van uitstaande gehalte was. Daarby het Herodus talle ander wonings dwarsoor Palestina gehad, soos by Jerigo, Masada, Herodium en Macherus (Fiensy 1991:158). Rohrbaugh (1988a:383; Vledder 1994:512) sluit die Herodiane in by die priesterlike klas, wat as aparte groep bestaan het. Die opperklas het bestaan uit hoë militêre offisiere, priesterlike families, die Herodiane en ander hooggeplaaste, aristokratiese families (kyk Saldarini 1988a:40; 1988b:200; Van Aarde 1993:529, 532).

\subsubsection{Die hoëpriesters}

Hulle is die volgende groep in die elite-klas. Dit was lede van adelike families waaruit die hoëpriesters gekies is (vgl Josefus War 6:114; Hand 4:6). Iemand moes in gebore wees in hierdie groep en op geen ander manier kon iemand lid van hulle word nie. Waarskynlik het hulle rykdom uit die tiendes en selfs van die tempelfondse geput (vgl Josefus Antiquities 20:181, 206; Vita 12, 15; b. Pes 57a). Hulle was welaf grondbesitters. In die Herodiaanse era het die meeste hoëpriesters uit een van vier families gekom, naamlik Boethus, Hanan, Kathros en Phiabi. Hulle het rykdom, aansien en posisie gehad en die meeste van hulle 
het waarskynlik in die hoër westelike deel van Jerusalem gewoon (vgl Fiensy 1991:160).

\subsubsection{Gewone aristokrate}

Hulle is die oudstes (presbuteroi) wat in Markus 15:1 en Handelinge 4:5 genoem word, asook leiers (proestotes), voormanne (protol) in Markus 6:21, die notables (gnorimol), magtiges (dunatai), diegene van hoë aansien (time) en geboorte (genos), asook die geëerdes (vgl Josefus War 2:316, 410, 411; Vita 185, 194; Yoma 6:4). Die drie ryk manne wat Jerusalem vir 21 jaar kon onderhou, is die grootstes van die land genoem. Hierdie klas was die nie-priesterlike en niekoninklike lede van die elite klas wat deur rykdom, aansien en prestasie, leiers van die gemeenskap geword het. Sommige van hulle was lede van die Sanhedrin in Jerusalem en waarskynlik plaaslike magistrate in kleiner dorpe (vgl Josefus War 2:237; 405; Antiquities 20:123; Vita 134). Hulle moes die belastinggaarders met die insameling van belastings behulpsaam gewees het (Fiensy 1991:160, 161). Die aristokrate en hulle ondersteunersklas het sowel in die stede as op die platteland oor die landvolk beheer uitgeoefen.

Sommige van hierdie welaf inwoners van Jerusalem het waarskynlik op dieselfde plek as die hoëpriesters gewoon. Hulle het nie alleen bewyse van groot rykdom in hulle huise agtergelaat nie, maar ook in hulle graftombes. Sodanige groepe het in Tiberias en Sefforis (vgl Josefus Vita 32-39) bestaan en daar is drie klasse in die gemeenskap onderskei: die grondeienaars, die kleinboere en die armes.

Fiensy (1991:160) maak nie melding van die skrifgeleerdes nie.

Rohrbaugh (1993a:384) beskou die skrifgeleerdes as deel van die stedelike elite (volgens die Markus-evangelie). Daarteenoor beskou ons die skrifgeleerdes as deel van die ondersteunende klas in Matteus (vgl Saldarini 1988a:161, 172). In die lydensverhaal word die skrifgeleerdes gemeld as Jesus se vyande in Jerusalem, saam met die oudstes en priesters (Matt 16:21; 20:18). In hierdie geval het hulle 'n politieke funksie (kyk Saldarini 1988a:161). Vledder (1994:514) vat die plek en funksie van die skrifgeleerdes soos volg saam: 
The scribes are also mentioned twice in the passion narratives as part of the complete leadership of Judaism (Mt 26:57, 59; 27:41). All these references symbolise the fact that the complete leadership of Jerusalem condemned and rejected Jesus. Therefore, strictly speaking, the scribes as pictured by the Gospel of Matthew did not really form part of the urban elite. They here have to be seen in relation to the other groups mentioned in these phrases.

\subsection{Die ondersteunende klas}

Hierdie klas het tussen die elite en die bestaansboere gestaan. Lenski (1991) glo dat die meeste agrariese gemeenskappe 'n ondersteunende klas gehad het om as tussenganger tussen die landvolk en die regeerders op te tree. Die ondersteunende klas het die politieke elite gedien. Hierdie mense het dikwels die vyandskap van die laer klasse beleef, omdat laasgenoemdes nooit presies kon vasstel waar hulle probleme vandaan gekom het nie. Die ondersteunende klas het die finansiële en politieke sake van die hoër klasse hanteer en hulle doelwitte afgedwing. Vir hierdie werk het hulle in die ekonomiese oorskot gedeel (Saldarini 1988a:41; 1988b:201; Rohrbaugh 1993a:385; Van Aarde 1993:532). Die grens tussen die hoër klas ondersteuner en die laer klas aristokraat was nie baie skerp getrek nie, net soos die grenslyn tussen die laer klas ondersteuner en die hoër klas kleinboer ook vaag was.

Van Aarde (1994:88) noem verskeie van die verteenwoordigers van ondersteunende klas, byvoorbeeld: “... burokrate, soldate en funksionarisse van die Hasmoniërs (en die Joodse elite-families wat as die nageslag van die Hasmoniese koninklike families beskou kan word), Herodiane en Romeine, asook tempelslawe en amptenare (soos die tempelpolisie) wat as 't ware besittings van die tempel was."

- Die tollenaars was lede van die ondersteunende klas (Josefus War 2:287; Saggeus van Jerigo in Luk 19:1-10 en Levi van Galilea in Luk 5:29 genoem, was lede van die groep). Hulle kon waarskynlik baie ryk gewees het. 
- Die rentmeester of die bestuurder, wat ook in die Herodiaanse era 'n belangrike rol gespeel het, is oikonomos ${ }^{13}$ genoem. In Lukas 16:1-8 en Lukas 12:42-48 word daar melding gemaak van hierdie mense. Hulle het aansienlike beheer oor hulle base se finansiële sake uitgeoefen en kon selfs bedrewe slawe gewees het (Fiensy 1991:163).

- Ons lees van die magistrate of wetstoepassers in Lukas 12:58 // Matteus 5:25 en dalk in Lukas 18:2 (Josefus War 2:571). Hulle het regsake verhoor en is in byna elke dorpie gevind. Die soldate het aan die Herodiane, die hoëpriesters en die Romeine behoort, asook aan die laer amptenare van die koningshuis.

- In die stede was handelaars, ambagsmanne en dagloners wie se lewenspeil gewissel het van gangbaar tot baie moeilik. Die handelaars kon die sogenaamde kleinhandel insluit en diegene wat op klein skaal met ingevoerde goedere handel gedryf het. Ambagsmanne kon, soos in die geval met tempelbouers, heel welaf wees, in elk geval beter af as die ongeskoolde arbeiders (Fiensy 1991:164).

Fiensy $(1991: 163,164)$ het 'n belangrike groep in die ondersteunende klas uitgelaat, naamlik die Fariseërs en Sadduseërs. Volgens Rohrbaugh (1993b:16), was die Fariseërs nie die dominante groep in die konflik met Jesus nie (volgens die Markus-evangelie). In die Matteus-evangelie was hulle wel die dominante groep opponente van Jesus (vgl Saldarini 1988a:167). Die Fariseërs, Sadduseërs en skrifgeleerdes vorm gesamentlik die leiers van die Joodse volk. Kingsbury (1987:58-59; 1988:17-24, 115-118; vgl Saldarini 1988c:70) beskou hierdie groep as 'n eenheid. Hulle almal wedywer vir mag en prestige (invloed) onder die Joodse volk. Slegs die motief en agenda van elke groep verskil van mekaar (vgl Saldarini 1988a:171). Volgens Vledder (1994:516) het hierdie groep net indirekte politieke mag in Matteus gehad (vgl Saldarini 1988a:172; 1988b:203). Die Fariseërs (asook die ondersteuners - vgl Saldarini 1988b:201), het waarskynlik hulle politieke mag gekry op 'n tyd toe die regerende klas nie doeltreffende regeerders was nie en die regeertaak in die hande van die ondersteunende klas gelaat is. Vledder (1994:516) beskryf die Fariseërs se gebruik van politieke mag in Matteus soos volg: "This opens up the possibility

${ }^{13}$ Die term kom in die volgende Rabbynse literatuur voor, naamlik Lev R. 12; Pesikta Rabbati 10; b. Shabb 153a; t. BM 9:14; t. Yom. Tob 4:9; t. BM 3:5; BB 4:7. 
that the Pharisees gained strong political influence within Judaism in the post-70 $A D$ period. It is also possible that the retainers, i e the Pharisees and scribes in Matthew, aspired to gain influence among the people, which could have intensified their conflict with the Matthean community."

\subsection{Die geostraseerdes}

Die huurders en dagloners het geen of min grond besit en het die meeste van hulle inkomste van grond verdien wat aan iemand anders behoort het. Slawe was op dieselfde ekonomiese vlak as dagloners, maar het ook nog hulle persoonlike vryheid verloor (kyk Osiek 1992b). Die onrein groepe is sowel in die stede as op die platteland gevind en was benede die gewone mense as gevolg van hulle beroep, afkoms of siektes. Onaanvaarbare beroepe was die prostitute, die misoptellers, donkiedrywers, dobbelaars, matrose, velverwerkers, herders en woekeraars. Diegene wat weens afkoms onaanvaarbaar was, is veral diegene wat as "onwettiges" gebore is. Hulle is buite-egtelike kinders wat nie in die vergadering van die Here kon binnegaan nie (Kidd 4:2; Lev 18; 20). Die tweede groep was die sogenaamde Gibeoniete wat deur Josua vervloek is en waarmee niemand mag getrou het nie. Die derde groep was diegene wat moes swyg as daar oor hulle herkoms gepraat word, omdat hulle nie hulle vaders geken het nie (kyk Fiensy 1991:165; Lenski 1991:203-204).

Daar is noukeurig boek gehou oor elke persoon se herkoms en in die rekords is vermeld dat iemand buite die eg gebore is en daarom onaanvaarbaar was (vgl Rabbynse literatuur, naamlik Yeb 4:13; Makk 3:1; Kidd 4:2). Dit blyk dat die nageslag van buite-egtelikes geneig het om ook sulke kinders te hê en daarom het hulle 'n subgroep gevorm. Die onreines vanweë siektes het die melaatses ingesluit wat buite die gemeenskap moes lewe.

\subsection{Die gemarginaliseerdes}

Hulle was die heel laagste op die sosiale leer. Dit was die struikrowers of misdadigers, die bedelaars en die half werkloses. Die agrariese gemeenskap kon slegs beperkte getalle werkers akkommodeer. Die struikrowers (vgl Horsley 
\& Hanson:1985:63-69) is aangevul met wegloperslawe, drostersoldate en verarmde bestaansboere. Struikrowery is as 'n georganiseerde vorm van openbare protes beskryf en is meestal verag (Josefus Antiquities 14:160, 165168; 20:118-136; War 2:228-231). Bedelaars was redelik bedrywig in Palestina. Dit het lammes ingesluit, asook blindes wat aan die kant van die pad gesit en bedel het. 'n Geliefkoosde plek vir die bedelaars was die tempel, omdat die gee van aalmoese daar 'n hoër aansien gehad het as elders (Fiensy 1991:166; Lenski 1991:204). Lenski (1991:217; vgl Duling 1992:105) gee die volgende voorstelling van die etic-macro social model van die sosiale stratifikasie in $90 \mathrm{vC}$ :

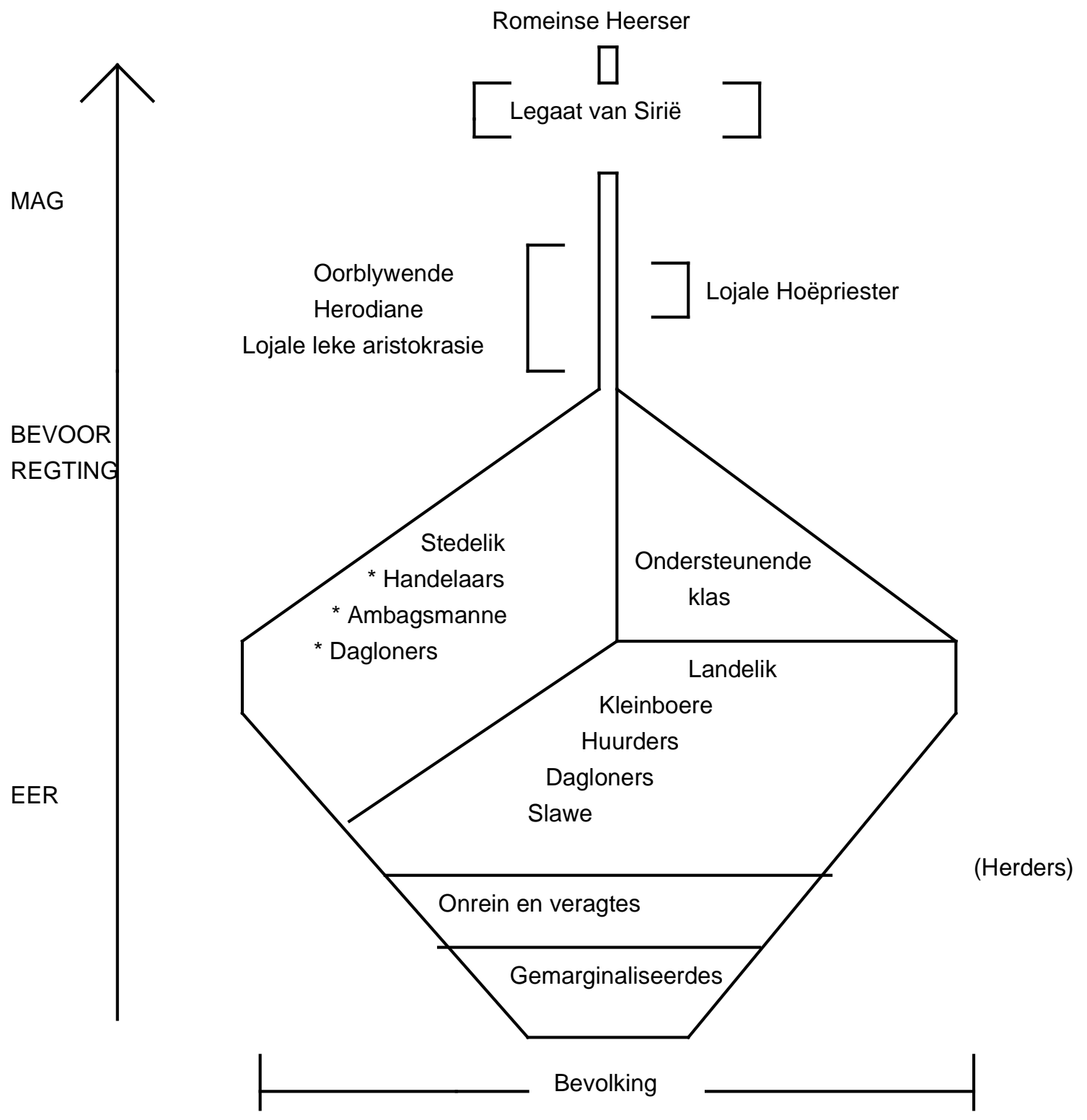




\section{SAMEVATTING}

Grond is inderdaad 'n bron van stryd in die gevorderde agrariese samelewing. Grondbesit en grondonteiening was vir die kleinboere 'n realiteit. Die sosiaalwetenskaplike model van die pre-industriële stad binne die gevorderde agrariese leefwêreld vorm die breë interpretasie raamwerk waarbinne die Bybelse jubilee (grondhervorming of kwytskelding van skuld) verstaan kan word. Die botsing oor grondbesit is veroorsaak deur die teenoorgestelde persepsies ( $\mathrm{vgl}$ afd 2.1) oor grond. Die elite beskou grond as 'n kapitale bate wat surplus opbrengs moet produseer, sodat wins gemaak kan word en meer grond aangekoop kan word. Die kleinboere het grond as 'n Godgegewe erfdeel, 'n onvervreembare erfreg beskou, wat ten alle koste beskerm moes word. Die verslawing of eksploitasie van ' $n$ volksgenoot is sonde. Die konflik is vererger deurdat die elite as afwesige grondeienaars in die stede gewoon en gewerk het. Hulle het deur middel van belastings die kleinboere verskuld of verslaaf, totdat hulle hulle grond verloor het.

In afdeling 2.2 is die bewerking van grond deur die dagloners, slawe en kleinboere bespreek. Die slawe en dagloners was soms beter af as die kleinboere, omdat hulle 'n swaar belastinglas, skuldlas en die risiko as gevolg van misoeste moes dra. Uit die inligting is dit duidelik dat die mense van die eerste-eeuse Mediterreense wêreld onder moeilike omstandighede geleef het. Die verskillende persepsies oor grondbesit en Jesus se reaksie daarop is in afdeling 2.3 aangetoon. Die bespreking bevestig dat grondbesit die middelpunt van die stryd was tussen die kleinboere en die elite.

Die eksploitasie en verslawing van die kleinboere en landvolk deur die elite, deur middel van belasting en skuld, is aangetoon. Jesus se kwytskelding van skuld moet tweeledig verstaan word: skuld moet as werklike finansiële skuld, asook morele skuld verstaan word. Verder pleit Jesus vir 'n sosiale orde wat in die basiese menslike behoefte (daaglikse brood) sal voorsien. Die werklike omvang van die betekenis van die kwytskelding van skuld sal in meer diepte teen die agtergrond van die Bybelse jubilee nagevors moet word. Die kritiek teen die verryking van die elite ten koste van die kleinboere vloei logies voort uit die beskrywing van die verknegting van die kleinboere. Die Matteus-evangelie en 
Jesus gee nie 'n felle kritiek teen die rykes nie. Wat wel na vore kom, is die kritiek op die sosiale orde wat selfgenoegsaamheid en privaat eiendom stel bo die omgee vir die sosiaal veragtes.

Die sosiale stratifikasie is 'n logiese uitvloeisel van die voorafgaande sosiaal-wetenskaplike model van die gevorderde agrariese samelewing. Die gebruik van die model sal 'n anakronisties-misplaaste vergelyking van die stratifikasie van die eerste-eeuse Mediterreense wêreld teenoor die moderne Marxistiese samelewingbeskouing vermy (kyk Van Aarde 1994:575-596 se kritiek). Die sosiaal-wetenskaplike model toon die radikale onderskeid aan, maar dien ook as interpretasie raamwerk waarbinne die sosiale struktuur van Palestina verstaan moet word. Die navorsing onderskei tussen orde, status en klas. Status is die primêre faktor in die stratifikasieproses van die eerste-eeuse Mediterreense wêreld. Status het tot langdurige politieke mag en rykdom gelei. Die sosiale struktuur van Palestina toon 'n duidelike hiërargiese struktuur. Die elite is ' $n$ klein persentasie van die samelewing, maar het die grootste sosioekonomiese en politieke mag besit. Hulle het die kleinboere deur middel van belastings geëksploiteer, totdat hulle later hulle plase verloor het. Die grootste deel van die bevolking het 'n minimum lewensbestaan gevoer. Die gemarginaliseerdes en geostraseerdes het op die onderste punt van die sosiale struktuur gestaan. Die rykes het al ryker geword en die armes armer.

\section{Literatuurverwysings}

Alföldy, G 1986. Die römische Gesellschaft. Wiesbaden: Steiner.

Ben-David, A 1974. Talmudische Ökonomie. Hildesheim: Georg Olms.

Blasi, A J 1986. Role structures in the early hellenistic church. Sociological Analysis 47, 226-248.

Brueggemann, W 1977. The land. Philadelphia: Fortress.

Charles, R H 1913 (ed). The apogrypha and pseudepigrapha of the Old Testament in English. 2 Vols. Oxford: Clarendon.

Crosby, M H 1988. The house of disciples: Church, economics and justice in Matthew. New York: Orbis Books. 
Davies, W D 1974. The gospel and the land: Early Christianity and Jewish territorial doctrine. Berkeley: University of California Press.

De Ste'Croix, G E M 1981. The class struggle in the ancient Greek world. New York: Cornell University Press.

Duling, D C 1992. Matthew's plurisignificant "Son of David" in social-science perspective: Kinship, kingship, magic and miracle. BTB 22, 99-116.

Fager, J F 1993. Land tenure and the Biblical Jubilee: Uncovering Hebrew ethics through the sociology of knowledge. (JSOT Supplement Series 155.)

Fiensy, D A 1991. The social history of Palestine in the Herodian period. Lewiston, NY: Edwin Mellen. (Studies in the Bible and early Christianity 20.)

Finley, M I 1985. The ancient economy. New York: Penguin Books.

Forster, G M 1965. Peasant society and the image of limited good. American Anthropologist 67, 293-315.

Goodman, M 1982. The first Jewish revolt and the problem of debt. Journal of Jewish Studies 30, 417-427.

Gregory, J R 1975. Image of limited good, or expectation of reciprocity? Current Anthropology 16, 73-92.

Harvey, A E 1982. The workman is worthy of his hire: Fortunes of a proverb in the early church. Novum Testamentum 24, 209-221.

Hengel, M 1974. Poverty and riches in the early church, tr by J Bowden. Philadelphia: Fortress.

Horsley, R A \& Hanson, J S 1985. Bandits, prophets, and messiahs: Popular movements in the time of Jesus. Minneapolis: Winston.

Josephus, F 1926-1956. Works, tr by Thackeray, H J et al. 10 vols. London: Harvard University Press.

Kee, $\mathrm{H} \mathrm{C}$ et al 1997. The Cambridge companion to the Bible. Cambridge: Cambridge University Press.

Kingsbury, J D 1987. The developing conflict between Jesus and the Jewish leaders in Matthew's Gospel: A literary-critical study. CBQ 49, 57-73.

Kingsbury, J D 1988. On following Jesus: The "eager" scribe and the "reluctant" disciple (Matthew 8.18-22). NTS 34, 45-59.

Klausner, J 1975. The economy of Judea in the period of the second temple, in AviYonah, M (ed), The Herodian period. London: Allen.

Koester, H 1994. The historical Jesus and the historical situation of the Quest, in Chilton, B \& Evans, C A (eds), Studying the historical Jesus?, 535-547. Philadelphia: Fortress. 
Lenski, G, Lenski, J \& Nolan P (1970) 1991. Human societies: An introduction to macrosociology. Sixth Edition. New York: McGraw-Hill.

Lenski, G E 1966. Power and privilege. New York: McGraw-Hill.

Meadland, D L 1980. Poverty and expectation in the gospels. London: SPCK.

Meeks, W A 1983. The first urban Christians: The social world of the apostle Paul. New Haven and London: Yale University Press.

Oakman, D 1986. Jesus and the economic questions of his day. Lewiston: Edwin Mellon. (SBEC 8.)

Oakman, D 1991. The countryside in Luke-Acts, in Neyrey JH (ed), 151-179. Peabody, MA: Hendrickson.

Oppenheimer, A 1977. The Am Ha-aretz, tr by Levine, I H. Leiden: Brill

Osiek, C 1992a. The social sciences and the second testament: Problems and challenges. BTB 22, 88-95.

Osiek, C 1992b. Slavery in the second testament world. BTB Readers guide 22, 174179.

Robertson, R 1987. sv Economics and religion. The encyclopedia of religion, vol 5, 111. New York: MacMillan Publishing Company.

Rohrbaugh, R L 1987. "Social location of thought" as a heuristic construct in New Testament study. JSNT 30, 103-119.

Rohrbaugh, R L 1993a. The social location of the Markan audience. Interpretation 47(4), 380-395.

Rohrbauch, R L 1993b. The social location of the Markan community. Un-published paper, The Context Group.

Saldarini, A J 1988a. Pharisees, scribes and Sadducees in Palestinian society: A sociological approach. Wilmington: Glazier.

Saldarini, A J 1988b. Political and social roles of the Pharisees and the scribes in Galilee, in Lull, D L (ed), SBL: 1988 Seminar Papers, 200-209. Atlanta: Scholars.

Saldarini, A J 1988c. The social class of the Pharisees in Mark, in Neusner et al, 69-77.

Singer, I 1903 (ed). Jewish encyclopedia. New York: Funk \& Wagnals.

Smith, R H 1980. Were the early Christians middle-class? A sociological analysis of the New Testament. Currents in Theology and Mission 7, 254-266.

Sperber, D 1965. Costs of living in Roman Palestine I. Journal of the Economic and Social History of the Orient 8, 248-271.

Stark, R 1986. The class basis of early Christianity: Inferences from a sociological model. Sociological Analysis 47, 216-225.

Van Aarde, A G 1988. Jesus en die sosiaal-veragtes. HTS 44(4), 829-846. 
Van Aarde, A G 1993. Aspekte van die sosiale stratifikasie van die ontwikkelde agrariese samelewing in die eerste-eeuse Palestina. HTS 49(3), 515-545.

Van Aarde, A G 1994a. God-with-us: The dominant perspective in Matthew's story. Pretoria: Gutenberg. (HTS Supp/5.)

Van Aade, A G 1994b. Kultuurhistoriese agtergrond van die Nuwe Testament: Die eerste-eeuse Mediterreense sosiale konteks. Pretoria: Kital.

Vledder, E J 1994b. The social stratification of the Matthean community. Neotestamentica 28(2), 511-522.

Vermes, G 1975. The Dead Sea Scrolls in English. New York: Penquin.

Weber, M 1947. The theory of social and economic organization, tr by Hender-son A M \& Parsons, T. New York: Free Press. 